FEDERAL RESERVE BANK OF SAN FRANCISCO

WORKING PAPER SERIES

\title{
Productivity Slowdown: Reducing the Measure of Our Ignorance
}

\author{
Timo Boppart, \\ IIES \\ Stockholm University \\ University of St. Gallen \\ Huiyu Li \\ Federal Reserve Bank of San Francisco \\ September 2021 \\ Working Paper 2021-21 \\ https://www.frbsf.org/economic-research/publications/working-papers/2021/21/
}

\section{Suggested citation:}

Boppart, Timo, Huiyu Li. 2021 "Productivity Slowdown: Reducing the Measure of Our Ignorance," Federal Reserve Bank of San Francisco Working Paper 2021-21.

https://doi.org/10.24148/wp2021-21

The views in this paper are solely the responsibility of the authors and should not be interpreted as reflecting the views of the Federal Reserve Bank of San Francisco or the Board of Governors of the Federal Reserve System. 


\title{
Productivity slowdown:
}

\section{reducing the measure of our ignorance*}

\author{
Timo Boppart ${ }^{\dagger} \quad$ Huiyu $\mathrm{Li}^{\ddagger}$
}

September 30, 2021

\begin{abstract}
Growth accounting suggests that the bulk of the post-2004 slowdown in output growth in the U.S. is attributed to a residual called TFP. In this paper we provide a tractable accounting framework with firm heterogeneity to link this residual to innovations, markup dispersion, and potential measurement errors. Theories of creative destruction offer rich testable predictions of how the quality upgrading of products, the process efficiency of different firms, and the markup dispersion in the market interact and therefore constitute a key approach to shed light on the slowdown in TFP growth. Surveying the literature on measurement, we conclude that measurement errors is unlikely to explain the recent deceleration in TFP growth.
\end{abstract}

JEL classification: O31, O47, O51.

Keywords: growth accounting, development accounting, growth slowdown, measurement, innovation.

${ }^{*}$ The views in this paper are solely the responsibility of the authors and should not be interpreted as reflecting the views of the Federal Reserve Bank of San Francisco or the Board of Governors of the Federal Reserve System. This draft was prepared for the conference volume "The Economics of Creative Destruction", a Festschrift in honor of Aghion and Howitt. We thank Philippe Aghion, John Fernald, Peter Howitt, Pete Klenow, and the participants of the conference for their helpful comments. We also thank Ufuk Akcigit, John van Reenen and the late Emmanuel Farhi for organizing the conference. Mitchell Ochse and Fabián Rivera-Reyes provided excellent research assistance.

${ }^{\dagger}$ Boppart: IIES, Stockholm University and University of St. Gallen

${ }^{\ddagger}$ Li: Federal Reserve Bank of San Francisco. 
Figure 1: Annual growth rates of GDP, labor productivity and TFP in four advanced economies

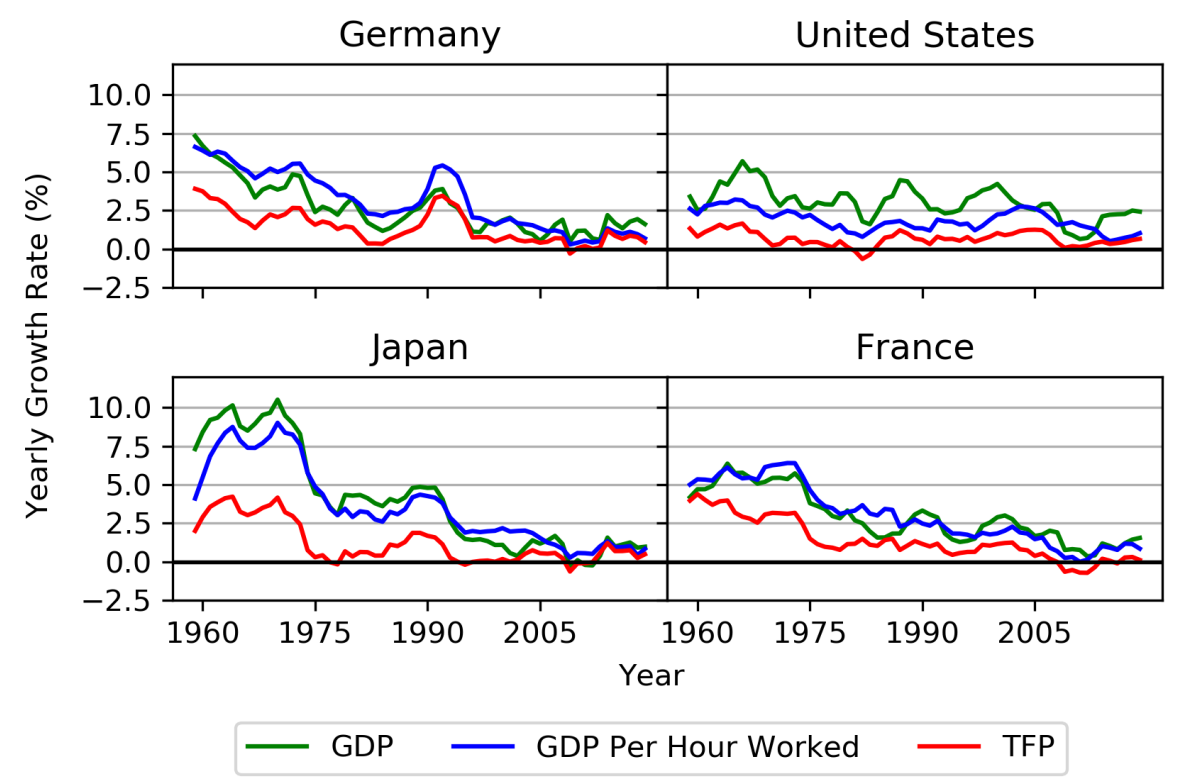

Source: Penn World Tables 10.0. 1960-2019. GDP = "rgdpna", TFP = "rtfpna", hours = "avh" times "emp", GDP per hours = "rgdpna" divided by hours. 5 year trailing moving averages.

\section{Introduction}

This short article is motivated by the recurring discussion about "secular stagnation". This discussion is due to disappointingly low observed growth rates of GDP, labor productivity, or TFP in advanced economies since the early 2000 s. Figure 1 illustrates this observation for the four countries Japan, U.S., Germany and France. In the recovery phase of World War II, in particular the German, Japanese and French economies were characterized by remarkably high growth rates. Subsequently, growth rates came down and labor productivity growth stabilized - with some bigger swings-at around 2 percent per year. However, since the early 2000s growth rates clearly fell short of this long-run average and did so in all the four selected countries.

The recently reported growth rates look indeed grim well beyond the four 
Figure 2: OECD averages

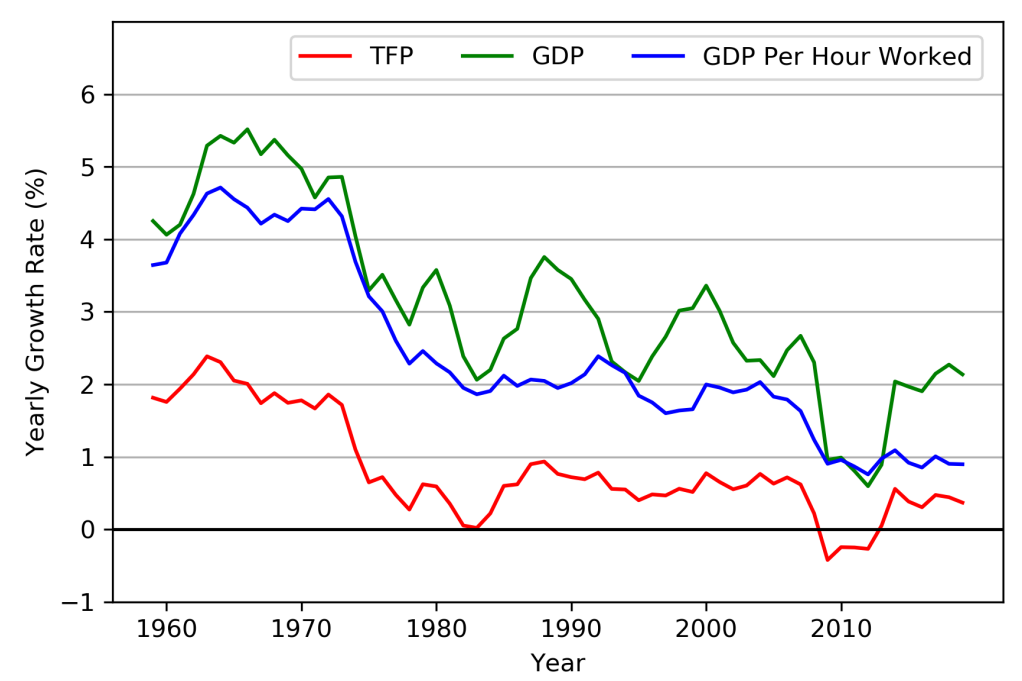

Source: Penn World Tables 10.0. 1960-2019. GDP = "rgdpna", TFP = "rtfpna", hours = "avh" times "emp", GDP per hours = "rgdpna" divided by hours. 5 year trailing moving averages. Average across countries is weighted by real GDP.

countries. Figure 2 shows the slowdown in the club of OECD countries. ${ }^{1}$ Will we in future no longer see the same steady growth rates? Have the advanced economies run out of their growth potential and if so why? Can policy do something about it? The welfare consequences of questions like these are simply staggering (Lucas, 1988) and they also have far-reaching implications for, e.g., the sustainability of pension systems or levels of debt in advanced economies.

In this short article we take a closer look at the productivity slowdown in the U.S. We show with a simple growth decomposition that the clear majority of the growth slowdown since the mid-90s cannot be accounted for by a slowdown in factor accumulation (labor quality, capital deepening) and therefore remains "unexplained", i.e., is attributed to a residual. We then provide a simple accounting framework to shed theoretical light on this unexplained "measure of our ignorance" called TFP. We argue that rich dynamics across firms and products determine aggregate TFP and that these forces consist of both growth rate

\footnotetext{
${ }^{1}$ Figure $\mathrm{Al}$ in the appendix shows that the productivity slowdown in non-OECD countries not as clearly visible, possibly due these economies being in transition of development.
} 
and level effects on productivity. We use our simple accounting framework to comment on potential measurement issues and discuss different mechanism of the productivity slowdown stressed in the literature. This analysis leads us to the conclusion that the creative destruction paradigm originating in Aghion and Howitt (1992) is a key theoretical framework to foster our understanding of the observed growth slowdown.

\section{Empirical facts}

Before returning to the productivity slowdown and studying the case of the U.S. more carefully we take a step back and more generally motivate what is really needed: a theory of total factor productivity (Prescott, 1998).

The macroeconomic data strongly suggest that simple factor accumulation based theories are not sufficient to account for output differences neither in the cross-section of countries nor in the time series. An often studied and tested prediction of the neoclassical growth model is its "convergence" property due to the diminishing marginal product of capital. Suppose all countries are identical except for their initial capital stock. Then the growth rates of all countries are expected to converge to the same level, e.g., country that start with a low initial capital stock is expected to shows subsequently above average output growth as the (detrended) capital stock increases along the transition towards its balanced-growth level. As a consequence, one expects a strong negative relationship between initial income levels (in say 1960) and the subsequent growth (1960-2019). Figure 3 shows that there is a lack of such "unconditional convergence" across countries post 1960. This finding has been used as a general motivation for endogenous growth theories. Interestingly, if one restricts the sample to OECD countries (Baumol, 1986), or the the post-2000 period as shown in Figure A2 in the appendix (see also Kremer, Willis and You (2021)), there emerges a clearer convergence pattern. Furthermore, Rodrik (2013) shows that there is more evidence for convergence in labor productivity within manufac- 
Figure 3: Convergence across countries 1960-2019

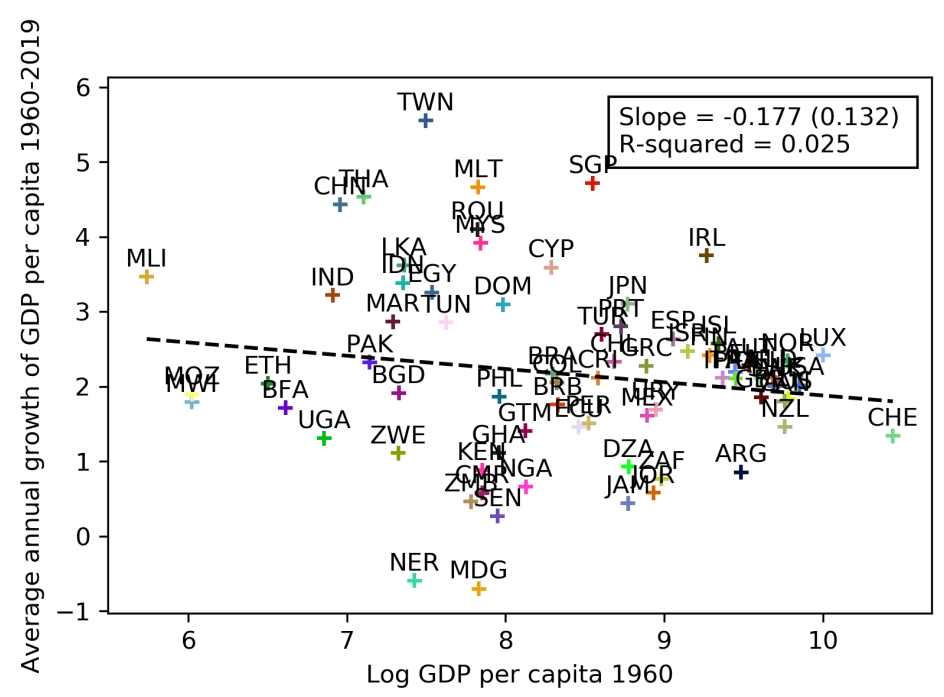

Source: Penn World Tables 10.0. Real GDP per capita = "rgdpna" divided by "pop". The x-axis plots the natural log of real GDP per capita in 1960. The y-axis plots the average annual growth rate of real GDP per capita over 1960-2019.

turing. Nevertheless, as the neoclassical theory predicts a very fast speed of convergence, even in cases where convergence is documented as, e.g., across U.S. states (see Barro, Sala-i Martin, Blanchard and Hall (1991)) there seems to be more than pure physical capital accumulation behind the phenomenon.

Another powerful argument against purely factor accumulation based explanations of income differences across countries constitutes the so called "development accounting" exercise as pioneered by Klenow and Rodriguez-Clare (1997) and Hall and Jones (1999). To fix ideas let us assume that aggregate output, $Y$, is produced according to a Cobb-Douglas production function

$$
Y=K^{\alpha}(\Gamma h L)^{1-\alpha},
$$

with the factors capital $K$, labor $L$ and human capital per worker $h$. The term $\Gamma$ captures TFP expressed in labor-augmenting units. All variables should be thought of as potentially being time variant as well as differing across countries. From a balanced-growth perspective a country with a higher level of $h$ or $\Gamma$ is 
endogenously expected to end up with a higher long-run capital stock. To see this let $\Gamma$ and $L$ grow at exogenous gross rates $\gamma$ and $\eta$ (where we normalize the initial level of $L$ to one) and for simplicity consider $h$ to be constant over time. Furthermore, we assume the following Solow-type capital accumulation equation

$$
K_{t+1}=K_{t}(1-\delta)+\Theta_{t} s K_{t}^{\alpha}\left(\Gamma_{0} \gamma^{t} h \eta^{t}\right)^{1-\alpha},
$$

where $0<s<1$ denotes the constant fraction of output being saved and $0<\delta<0$ the depreciation rate. The term $\Theta_{t}$ captures an investment specific technology term which is assumed to grow at constant rate, i.e., $\Theta_{t}=\Theta_{0} \theta^{t}$. With $\theta>1$ this captures investment-specific technical change (Greenwood, Hercowitz and Krusell, 1997). In a competitive framework the price of investment relative to output is given by $\Theta_{t}^{-1}$ and therefore shrinks over time at gross rate $\theta^{-1}<1$. Along a balanced-growth path we have $\frac{K_{t+1}}{K_{t}}=\eta \gamma \theta^{\frac{1}{1-\alpha}}$ and $\frac{Y_{t+1}}{Y_{t}}=$ $\eta \gamma \theta^{\frac{\alpha}{1-\alpha}} \equiv g$. We can then reformulate the production function in (1) to express output per worker as

$$
\frac{Y_{t}}{L_{t}}=\left(\frac{g}{\eta}\right)^{t} \cdot \underbrace{\Gamma_{0} \Theta_{0}^{\frac{\alpha}{1-\alpha}}}_{=A} \cdot h \cdot\left(\frac{\Theta_{t}^{-1} K_{t}}{Y_{t}}\right)^{\frac{\alpha}{1-\alpha}} .
$$

Consider all countries being along their balanced-growth path and only differing in their saving rate $s$, the initial level of technology $A=\Gamma_{0} \Theta_{0}^{\frac{\alpha}{1-\alpha}}$ and the level of human capital $h$. From the capital accumulation equation, we have $\frac{\Theta_{t}^{-1} K_{t}}{Y_{t}}=$ $\frac{s}{g \theta-1+\delta}$ along the balanced-growth path which is constant over time and just depends on $s$ but is independent of $h$ and $A$. Hence, from a balanced-growth perspective, (3) is a theory consistent way to decompose GDP per worker differences across countries into differences in physical and human capital as well as a residual term $A$.

The standard development accounting exercise abstracts from investmentspecific technological change (i.e., assumes $\Theta_{0}=\theta=1$ ) in which output per 
worker in a country $i$ in (3) simplifies to

$$
\frac{Y_{i, t}}{L_{i, t}}=(g / \eta)^{t} A_{i} h_{i}\left(\frac{K_{i, t}}{Y_{i, t}}\right)^{\frac{\alpha}{1-\alpha}} .
$$

where $Y / L$ is real output per worker. Human capital in terms of efficiency units $h$ can be quantified in a standard way using years of education of the labor force plus Mincerian returns, output per worker is readily available from the Penn World Tables (PWT) and $K / Y$ can be quantified by the measure of the real capital stock relative to real GDP. ${ }^{2}$ Then, together with a estimate for $\alpha$ (which can be set to $1 / 3$ to match the U.S. capital income share), accounting equation (4) can be used to decompose income differences into differences in human capital $h$, physical capital $(K / Y)^{\frac{\alpha}{1-\alpha}}$ and a residual $A$ that we can call TFP.

Table 1 shows the decomposition for some selected countries with recent data from the year 2018. ${ }^{3}$ Multiplying the numbers of the last three columns by each other gives by construction the value of the second column. Furthermore, the entries of all columns are normalized to one in the U.S., i.e., the numbers can be interpreted as relatives to the U.S. Take the example of Nigeria which is one tenth as rich as the U.S.: what accounts for this income difference? It is not physical capital accumulation as $K / Y$ is roughly as big as in the U.S. There is a clear difference in the average level of human capital between Nigeria and the U.S., but only by a factor of about two. Hence the majority of the observed income difference of a factor of ten remains unaccounted for by production factors differences and is consequently absorbed by the residual term $A$. This is indeed the general take-away message from development accounting exercises.

Figure 4 illustrates the relationship between the logarithm of output per worker and the logarithm of the residual TFP. If differences in physical and human capital did not account for any of the observed income differences we would expect the data points to cluster around the 45-degree line. If in contrast

\footnotetext{
${ }^{2}$ We remove resource rents from output using resource shares calculated by Julieta Caunedo from the World Development Index, which is available until 2018.

${ }^{3}$ We provide the results of the full list of countries in the appendix.
} 
Table 1: Development accounting

\begin{tabular}{lcccc} 
Country & $Y / L$ & $(K / Y)^{\frac{\alpha}{1-\alpha}}$ & $h$ & $A$ \\
\hline United States & 1.000 & 1.000 & 1.000 & 1.000 \\
Switzerland & 1.002 & 1.214 & 0.987 & 0.836 \\
France & 0.806 & 1.342 & 0.857 & 0.701 \\
Germany & 0.753 & 1.194 & 0.981 & 0.642 \\
Sweden & 0.805 & 1.248 & 0.915 & 0.705 \\
Japan & 0.565 & 1.236 & 0.957 & 0.477 \\
Republic of Korea & 0.624 & 1.229 & 0.996 & 0.510 \\
Russian Federation & 0.379 & 1.277 & 0.913 & 0.325 \\
Mexico & 0.341 & 1.165 & 0.736 & 0.397 \\
Argentina & 0.388 & 0.995 & 0.819 & 0.476 \\
Brazil & 0.247 & 1.173 & 0.806 & 0.261 \\
China & 0.190 & 1.189 & 0.714 & 0.224 \\
India & 0.139 & 1.065 & 0.574 & 0.227 \\
Nigeria & 0.099 & 1.007 & 0.521 & 0.188 \\
Kenya & 0.068 & 0.852 & 0.621 & 0.128 \\
Zimbabwe & 0.048 & 0.703 & 0.716 & 0.095
\end{tabular}

Source: Penn World Tables 10.0. $\tilde{Y}=$ "rgdpo", s = natural resource shares from World Development Index, $Y=\tilde{Y}(1-s), \mathrm{L}=$ "emp", $\mathrm{K}=$ "cn" , h = "hc". $A=\frac{Y}{(K / Y)^{\frac{\alpha}{1-\alpha}} h L}$ with $\alpha=1 / 3$.

all income differences were accounted for by differences in physical and human capital we would expect a completely flat relationship (and all TFP observations would cluster around a value of zero). The implied TFP levels in Figure 4 show an elasticity in output per worker of 0.72 and are therefore relatively close to the 45-degree line. We therefore conclude that the majority of observed crosscountry income differences remains "unexplained" by differences in physical 
and human capital.

How would this standard result of development accounting change through the lens of a theory that allows for differences in the investment-specific technology term (over time and across countries)? In this case there are two goods: an investment and a consumption good with a relative price between them captured by the term $\Theta_{t}^{-1}$. The left-hand side of (3) expresses output per worker in consumption units and can be measured as such by deflating nominal output by PPP-adjusted consumption prices. Furthermore, the theory in (3) adjust the ratio of real capital to real output in (4) by the relative price $\Theta_{t}^{-1}$. To make this adjustment we multiply the real capital-output ratio by the price of investment relative to the consumption. Figure 5 shows the scatter plot between log output per worker and the resulting log TFP if this adjusted capital-output ratio is used. ${ }^{4}$ As the relative price of investment is higher in poor countries (Hsieh and Klenow, 2007) the adjusted capital-output ratio results in a higher measures of physical capital in poor countries (compared to the rich) and therefore in an even larger "unexplained" part of the income differences. As a consequence, the slope of the fitted line in Figure 5 is steeper than the fitted line in Figure 4 (0.87 vs. 0.72 ).

Using the relative price investment, we can use (3) to further decompose the differences in $A$ across countries into difference in $\Gamma_{0}$ and $\Theta_{0}^{\frac{\alpha}{1-\alpha}}$. For the countries in Figure 5, the elasticity of the relative price of investment to consumption goods with respect to real GDP per worker in consumption units is $-0.170 .{ }^{5}$ This implies that the elasticity of $\Theta_{0}^{\frac{\alpha}{1-\alpha}}$ with respect of GDP per worker is about 0.085 , which is one order of magnitude smaller than the 0.87 elasticity of residual TFP in Figure 5. Hence, according to this quantification, differences in the

\footnotetext{
${ }^{4}$ In the appendix we show the complete break down into physical and human capital differences as well as the residual for all the countries.

${ }^{5}$ The elasticity is the coefficient on log GDP per worker when we regress log relative price of investment to consumption on log GDP per worker in consumption units and a constant. The relative price of investment equals $p l_{-} i / p l_{-} c o n$, where $p l_{-} i$ is the price level of capital formation and $p l_{-}$con is the price level of real consumption of households and government (PPP/XR). See footnotes of Figure 5 for the construction of real GDP per worker in consumption units.
} 
Figure 4: Development accounting: implied TFP terms

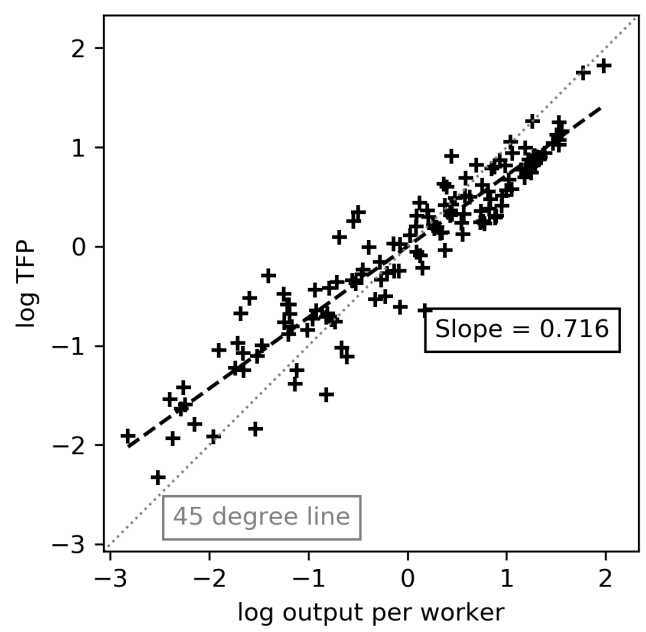

Source: Penn World Tables 10.0. $\tilde{Y}=$ "rgdpo", $\mathrm{s}=$ natural resource shares from World Development Index, $Y=\tilde{Y}(1-s), \mathrm{L}=$ "emp", $\mathrm{K}=$ "cn" , $\mathrm{h}=$ "hc". $A=\frac{Y}{(K / Y)^{\frac{\alpha}{1-\alpha}} h L}$ with $\alpha=1 / 3$. Each point is a country in 2018. The x-axis (y-axis) is deviation of a country's log Y/L (log TFP) from the mean across countries. The slope is the coefficient on $\log \mathrm{Y} / \mathrm{L}$ when regressing the $\mathrm{y}$-axis values on the $\mathrm{x}$-axis values.

Figure 5: Development accounting with investment-specific technology

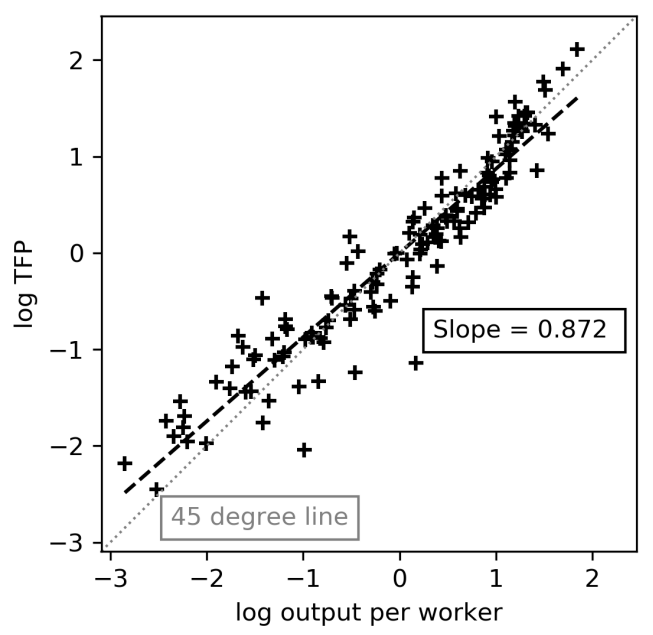

Source: Penn World Tables 10.0. $\tilde{Y}=$ "rgdpo", $\mathrm{s}=$ natural resource shares from World Development Index, $\mathrm{Y}=\tilde{Y}(1-s)$ times "pl_gdpo" divided by "pl_con", L = "emp", $\mathrm{K}=$ "rnna" /"pl_n", $\mathrm{h}=$ "hc", $\Theta^{-1}=$ "pl_i" divided by "pl_con". $A=\frac{Y}{\left(\Theta^{-1} K / Y\right)^{\frac{\alpha}{1-\alpha}} h L}$ with $\alpha=1 / 3$. Each point is a country in 2018. The x-axis (y-axis) is deviation of a country's log Y/L (log TFP) from the mean across countries. The slope is the coefficient on $\log \mathrm{Y} / \mathrm{L}$ when regressing the $\mathrm{y}$-axis values on the $\mathrm{x}$-axis values. 
investment-specific technology term explains only a relatively small fraction of the residual TFP differences across countries.

\section{Taking a closer look at the U.S. time series}

In the previous section we documented that factor accumulation based theories fall short of explaining income level differences across countries, i.e., a theory of TFP is needed. In the following we focus on the U.S. economy and do a Solow growth decomposition to see to what extent factor based explanations can account for the observed slowdown in output growth. Suppose again that output is produced according to the production function in (1) which we can rewrite in per-worker terms as

$$
\frac{Y_{t}}{L_{t}}=\Gamma_{t}^{1-\alpha}\left(\frac{K_{t}}{h_{t} L_{t}}\right)^{\alpha} h_{t},
$$

Taking time differences of the logarithm of both sides of (5) allows us to do a growth decomposition and back out $g_{T F P, t} \equiv(1-\alpha) \log \left(\Gamma_{t+1} / \Gamma_{t}\right)$ as

$$
g_{T F P}=g_{y}-\alpha \cdot g_{k}-g_{h},
$$

where $g_{y}$ denotes the growth rate in labor productivity, $y \equiv Y / L, g_{k}$ the growth rate in the capital intensity $k \equiv K /(h L)$, and $g_{h}$ the growth rate in human capital. Table 2 performs this decomposition for the U.S. economy using the FRBSF TFP data. Following the literature on the U.S. growth decline, we compare average annual growth rates over the two periods $1996-2004$ and 2005-2019. ${ }^{6}$ The second column shows the slowdown in labor productivity growth. Over the decade after the mid 90s the U.S. economy experience a burst in productivity growth at an average annual rate of more the 3 percent. This number decreased by about

\footnotetext{
${ }^{6}$ Using statistical break tests, Fernald (2015) find a high growth regime from mid 1990s to early 2000 and a slowdown after 2004. We do not use data post 2019 because of large cyclical fluctuations during the COVID pandemic.
} 
1.9 percentage points to only 1.4 percent for the post-2004 period. Columns (3)-(5) then decompose this slowdown in labor productivity into TFP, $g_{T F P}$, capital deepening $\alpha \cdot g_{k}$ and labor quality $g_{h}$. Comparing the two periods shows that capital deepening did slow down but only by about half a percentage point whereas the improvement of labor quality actually slightly accelerated. Hence about three-fourth of the slowdown is unaccounted for by factor accumulation and absorbed by the residual TFP.

Table 2: Sources of U.S. labor productivity growth

\begin{tabular}{c|cccc} 
& $\begin{array}{c}\text { Labor } \\
\text { productivity }\end{array}$ & TFP & $\begin{array}{c}\text { Capital } \\
\text { deepening }\end{array}$ & $\begin{array}{c}\text { Labor } \\
\text { quality }\end{array}$ \\
\hline $1996-2004$ & 3.32 & 1.82 & 1.13 & 0.36 \\
$2005-2019$ & 1.39 & 0.45 & 0.54 & 0.40 \\
\hline Change & -1.93 & -1.37 & -0.59 & 0.03 \\
\% of LP change & & $\mathbf{7 1}$ & 30 & -2
\end{tabular}

Source: Fernald, Li and Ochse (2021), FRBSF TFP database version: June 7th 2021. The first and second rows are average annualized growth rates in percentage points over 1996Q1-2004Q4 and 2005Q1-2019Q4, respectively. The third row equals row 2 minus row 1 . The last row is the values in the third row divided by the change in labor productivity, expressed as a percent. TFP equals labor productivity growth minus capital deepening and labor quality.

Hence when it comes to studying the observed slowdown in output growth there is clear evidence that a simple factor accumulation based story is not sufficient. Consequently there is a potential role to play for theories of endogenous growth in explaining the slowdown. In the next section we sketch a theoretical accounting framework. This framework is then used to comment on measurement issues and to shed some theoretical light on what might be behind the change in residual TFP growth. 


\section{An accounting framework with heterogeneous firms and products}

Suppose final output in the economy is a Cobb-Douglas composite defined over $N$ varieties

$$
Y=\exp \left[\frac{1}{N} \int_{0}^{N} \log \left[N^{1+\nu} q(i) y(i)\right] d i\right]
$$

and produced competitively. The term $N^{1+\nu}$ is added to introduce a separate parameter $\nu$ that controlled the taste for variety. Product varieties come at quality $q(i)$ and are produced according to

$$
y(i)=\varphi(i) \cdot k(i)^{\alpha} \cdot(h l(i))^{1-\alpha},
$$

where $\varphi(i)$ denotes a variety-specific productivity term. Firms producing intermediate products are assumed to charge a price, $p(i)$, equal to a markup $\mu(i)$ over marginal cost

$$
p(i)=\frac{\mu(i)}{\varphi(i)} \cdot r^{\alpha} \cdot w^{1-\alpha} \cdot \alpha^{-\alpha}(1-\alpha)^{-(1-\alpha)} .
$$

All variables and parameters here could be thought of as being time-varying. We simply assume some exogenous levels of markup and do not micro-found the industry structure in detail. We do not embed this framework in general equilibrium either but instead simply close the production side by capital and labor market clearing $K_{t}=\int_{0}^{N} k_{t}(i) d i$, and $L_{t}=\int_{0}^{N} l_{t}(i) d i$, assume perfectly mobile production factors and competitive factor markets and then determine the level of aggregate output.

Aggregate output With a perfectly competitive final output market, the CobbDouglas structure implies as demand for each variety $y(i)=\frac{Y P}{p(i)}$, where $P$ denotes the aggregate price index $P \equiv N^{-\nu} \exp \left(\frac{1}{N} \int_{0}^{N} \log [p(i) / q(i)] d i\right)$. The capital intensity, $\frac{k(i)}{h l(i)}$, will equalize across all firms. By aggregating up we then obtain 
for the level of real output

$$
Y=\underbrace{N^{\nu} \cdot Q \cdot \Phi \cdot \mathcal{M}}_{=T F P} \cdot K^{\alpha} \cdot(h L)^{1-\alpha},
$$

where $Q$ denotes the geometric average of the quality levels $q(i)$,

$$
Q=\exp \left(\frac{1}{N} \int_{0}^{N} \log (q(i)) d i\right)
$$

$\Phi$ denotes the geometric average of the process efficiency levels $\varphi(i)$

$$
\Phi=\exp \left(\frac{1}{N} \int_{0}^{N} \log (\varphi(i)) d i\right)
$$

and $\mathcal{M}$ is a measure of markup dispersion

$$
\mathcal{M}=\frac{\exp \left(\frac{1}{N} \int_{0}^{N} \log \frac{1}{\mu(i)} d i\right)}{\frac{1}{N} \int_{0}^{N} \frac{1}{\mu(i)} d i} .
$$

The measure $\mathcal{M}$ can be viewed as the ratio of the geometric and arithmetic average of the inverse markup and is therefore smaller (or equal) to one. Without markup dispersion we would have $\mathcal{M}=1$.

Interestingly, the aggregate production function boils down to the same overall structure as in (1). As a consequence, in a reduced form the same growth decomposition as in (6) can be obtained from this framework. But (10) further decomposed the TFP term is into the effect of the gains from variety, the level of product quality, the level of process efficiency and the markup dispersion. ${ }^{7}$ This allows us to further speak to the underlying sources of a slowdown in TFP growth as emphasized by theories of endogenous growth and firm heterogeneity. Some, like the changes in the allocative efficiency $\mathcal{M}$ (or sometimes also the level of process efficiency $\Phi$ ) are typically thought of as level effect that mate-

\footnotetext{
${ }^{7}$ Due to the Cobb-Douglas structure this different component enter log additively. Under a more general CES specification the interactions of quality, process efficiency, and markups would matter too.
} 
rialize over a transitional period. Others like the effect of variety expansion $N$ or quality $Q$ are typically thought of as showing a long-run trend through which effects on the growth rate enter. Modern theory of endogenous growth typically offer a rich micro-founded theories of markup and productivity dispersion across firms as well as quality upgrading and therefore speak to the precise terms highlighted in (10). In Section 6 below we highlight some examples from the literature that speak to the productivity slowdown. Before we turn to this we first discuss how measurement error may influence the quantification of Solow's residual and whether the measured productivity slowdown could just come from increasing measurement issues.

\section{Growth decline due to measurement error?}

As shown in Table 2, the decline in measured TFP growth accounts for the bulk of decline in output growth in the U.S. since the mid 2000s. Is this slowdown in productivity growth real or a figment of increasing measurement error? In this section, we first survey recent measurement literature and discuss possible sources of increasing understatement of growth. We find that increasing "missing growth" cannot explain the bulk of the slowdown.

\subsection{True vs. measured growth}

Let us first lay down some equations to clarify the relationship between measurement and growth decline. For concreteness, consider the accounting framework from the previous section. From equation (10) in the framework, true TFP growth coincides with equation (6) or

$$
g_{T F P}=g_{Y}-g_{L}-\alpha \cdot g_{k}-g_{h}
$$


Measured TFP growth is given by

$$
\widehat{g}_{T F P}=\widehat{g}_{Y}-\widehat{g}_{L}-\widehat{\alpha} \cdot \widehat{g}_{k}-\widehat{g}_{h}
$$

where $\widehat{x}$ denotes the measured value of variable $x$.

For simplicity, suppose the growth in the number of workers is measured well so that $g_{L}=\widehat{g}_{L}$. Then, missing TFP growth arises from understating output growth or overstating input growth. That is, the difference between true and measured productivity growth is given by

$$
\begin{aligned}
g_{T F P}-\widehat{g}_{T F P}= & g_{Y}-\widehat{g}_{Y} \\
& +\alpha \cdot\left(\widehat{g}_{k}-g_{k}\right)+\left(\widehat{g}_{h}-g_{h}\right) \\
& +(\widehat{\alpha}-\alpha) \cdot \widehat{g}_{k}
\end{aligned}
$$

where (13) is missing output growth, (14) is overstating the growth of capital inputs and growth of labor quality and (15) is mismeasuring the production elasticity of capital. When there are rents or quasi rents, standard measures of TFP growth tend to overstate the production elasticity $(\widehat{\alpha}>\alpha)$ because standard measurements use one minus the value-added share of labor to estimate $\alpha$. In our accounting framework, this estimate corresponds to $\widehat{\alpha}=(r K+\Pi) /(r K+$ $w L+\Pi)$, where $\Pi$ is the sum of firm profits. However, the capital production elasticity in our framework is equal to one minus the cost share of labor or $\alpha=$ $r K /(r K+w L)$ and is smaller than $\widehat{\alpha}$ when $\Pi>0$. Since there is usually capital deepening in the data, $\widehat{g}_{k}>0$ and overstating $\alpha$ results in understating TFP growth. ${ }^{8}$

There are many studies of measurement errors in (13)-(15). For example, on missing output growth, there is large and long-standing literature since the Boskin commission (Boskin, Dullberger, Gordon, Grilliches and Jorgenson, 1996) that finds significant levels of missing output growth due to measured output

\footnotetext{
${ }^{8}$ See Fernald and Neiman (2011) for an application to Singapore.
} 
deflators not fully capturing substitution, new goods and quality improvements. However, (13)-(15) are about biases in the level of growth while the discussion of decline in growth is about the change in the growth rate. The time difference between changes in the true growth rate and measured growth rate is

$$
\begin{aligned}
\Delta g_{T F P}-\Delta \widehat{g}_{T F P}= & \Delta\left(g_{Y}-\widehat{g}_{Y}\right) \\
& +\Delta \alpha\left(\widehat{g}_{k}-g_{k}\right)+\Delta\left(\widehat{g}_{h}-g_{h}\right) \\
& +\Delta(\widehat{\alpha}-\alpha) \widehat{g}_{k},
\end{aligned}
$$

where $\Delta x$ denotes the change in $x$ over time. The decline in measured TFP growth correctly captures the decline in true growth $\left(\Delta g_{T F P}=\Delta \widehat{g}_{T F P}\right)$ if measurement errors stayed constant over time, even if these errors are large on average. Hence, for true TFP growth to decline less than measured TFP growth $\left(\Delta g_{T F P}>\Delta \widehat{g}_{T F P}\right)$, one needs to show that understatements of output growth increased over time.

\subsection{Has missing growth increased?}

First, let us consider whether missing output growth (16) has increased. For the U.S. private business sector, recent research has not found significant increase in missing output growth. Moulton (2018) argues that inflation measurement error has not gotten worse since the Boskin commission while Aghion, Bergeaud, Boppart, Klenow and Li (2019) find that missing growth from unmeasured creative destruction innovation and new varieties are significant in levels but have not increased since the early 1980s. Furthermore, Fernald (2015), Byrne, Fernald and Reinsdorf (2016) and Syverson (2017) argue that more missing growth in the ICT sector cannot account for post-2005 slowdown in U.S. productivity growth. Similarly, Guvenen, Mataloni, Rassier and Ruhl (2017) did not find offshore profit shifting contributing significantly to the measured 
slowdown in output growth. ${ }^{9}$ One important margin that can potentially lead to large revisions of the level of output is the capitalization of intangible and R\&D expenditures (Koh, Santaeulàlia-Llopis and Zheng, 2020). However, Brynjolfsson, Rock and Syverson (2021) find that mismeasurement of intangible investments does not explain the productivity slowdown post mid 2000s because correcting the measurement error raised productivity growth before and after mid 2000s. Recent work by Crouzet and Eberly (2021) argues that the rise in intangible investments may have contributed to the slowdown in measured TFP growth post-1997 compared to pre-1997.

Even if missing output growth has not increased, measured TFP growth may have declined because we are becoming better at measuring inputs. For example, TFP growth is overstated if quality improvements in inputs are understated. Hence, measured TFP growth can decline if we have become better at measuring quality improvements in inputs. However, we are not aware of studies that find input measurement errors contributing significantly to the recent slowdown in TFP growth in the U.S.

Lastly, various studies have documented rising markups in the economy. If this trend reflects a rise in the share of rents or quasi-rents, then (18) may have increased and contributed to a slowdown in measured TFP growth. On the other hand, the effect of this measurement error may have been dampened by a significant slowdown in capital deepening. In Table 2, capital deepening $\widehat{\alpha} \cdot \widehat{g}_{k}$ halved. Within this component, the measured capital share $\widehat{\alpha}$ increased from an average of 0.33 to 0.38 , while $\widehat{g}_{k}$ slowed from 3.53 to 1.51 percent per year. If true $\alpha$ stayed relatively constant over time at around 0.30 (which implies that the rent share of GDP increased from $4 \%$ to $11 \%$ of GDP), then the third component (18) has not increased. ${ }^{10}$ In this back-of-the envelope calculation, the increasing measurement error in $\alpha$ does not contribute significantly to the

\footnotetext{
${ }^{9}$ Some studies such as Brynjolfsson, Collis, Diewert, Eggers and Fox (2019) and Hulten and Nakamura (2019) however argue that missing output growth in non-market economy may have increased due to the rising prevalence of free goods.

${ }^{10}$ This is equal to $(0.38-0.30) 1.51-(0.33-0.30) 3.53=-0.14$. Crouzet and Eberly (2021) also find small effects from this markup measurement channel.
} 
decline in measured TFP growth because capital deepening has slowed down.

Overall, our survey of the measurement literature suggests that individual changes in measurement error do not contribute significantly to the decline in TFP growth.

\section{Concluding remarks and outlook}

Output growth has slowed down in the U.S. and other advanced economies, with a large part of the slowdown coming from a decline in TFP growth. This paper provides an accounting framework that links TFP growth to innovation and allocative efficiency and clarify the relationship between true TFP growth and measured TFP growth. Surveying the measurement literature, we find that it is likely that a large part of the decline in measured TFP growth is in fact real.

There are several strands of explanation in the literature for what caused the decline in true TFP growth. One major strand investigates forces that changed the competitive environment, which in turn affects innovation and allocative efficiency, e.g., Aghion, Bergeaud, Boppart, Klenow and Li (2021), Akcigit and Ates (2021), Autor, Dorn, Katz, Patterson and Van Reenen (2020), Edmond, Midrigan and Xu (2018), De Loecker, Eeckhout and Unger (2020), Gutierrez and Philippon (2017). Other possible explanations are slowing population growth (Peters and Walsh (2020), Hopenhayn, Neira and Singhania (2020)), ideas getting harder to find (Gordon (2016), Bloom, Jones, Van Reenen and Webb (2020)) and declining discount rate (Farhi and Gourio (2018), Liu, Mian and Sufi (Forthcoming), Chikis, Goldberg and López-Salido (2021)). Finally, Baqaee and Farhi (2020) and Bils, Klenow and Ruane (2020) suggest that allocative efficiency may have declined in the U.S.

Through the lens of our framework, these theories operate through one or several of the channels $\Phi, Q, N, \mathcal{M}$ in equation (10). We believe that the Schumpeterian growth theory à la Aghion and Howitt (1992) is a key approach to understanding the productivity slowdown because it offers rich testable predic- 
tions for quality, process efficiency, markup dispersion as well as rich policy implications such as for antitrust.

Finding the source of the TFP growth decline, however, is ultimately a quantitative question because theoretical prediction can be ambiguous-e.g., the effect of competition has both positive (escape from competition) and negative (discouragement) effects on innovation (Aghion, Bloom, Blundell, Griffith and Howitt, 2005). Our view is that structural models disciplined by micro moments is a promising approach. Hence we hope that there will be more micro data such as product-level prices and quantities of output, or plant and firm level measures of inputs and $R \& D$ (especially outside of manufacturing) to make headway on this important question.

\section{References}

Aghion, Philippe and Peter Howitt, "A Model of Growth through Creative Destruction," Econometrica, 1992, 60 (2), 323-351.

_ , Antonin Bergeaud, Timo Boppart, Peter J Klenow, and Huiyu Li, "Missing growth from creative destruction," American Economic Review, 2019, 109 (8), 2795-2822.

${ }_{-},{ }_{-},{ }_{-}$, and $\ldots$, "A theory of falling growth and rising rents," Technical Report, working paper 2021.

_ , Nick Bloom, Richard Blundell, Rachel Griffith, and Peter Howitt, "Competition and innovation: An inverted-U relationship," The quarterly journal of economics, 2005, 120 (2), 701-728.

Akcigit, Ufuk and Sina T Ates, "Ten facts on declining business dynamism and lessons from endogenous growth theory," American Economic Journal: Macroeconomics, 2021, 13 (1), 257-98. 
Autor, David, David Dorn, Lawrence F Katz, Christina Patterson, and John Van Reenen, "The fall of the labor share and the rise of superstar firms," Quarterly Journal of Economics, 2020, 135 (2), 645-709.

Baqaee, David Rezza and Emmanuel Farhi, "Productivity and misallocation in general equilibrium," Quarterly Journal of Economics, 2020, 135 (1), 105-163.

Barro, Robert J, Xavier Sala i Martin, Olivier Jean Blanchard, and Robert E Hall, "Convergence across states and regions," Brookings papers on economic activity, 1991, pp. 107-182.

Baumol, William J, "Productivity growth, convergence, and welfare: what the long-run data show," The american economic review, 1986, pp. 1072-1085.

Bils, Mark, Peter J Klenow, and Cian Ruane, "Misallocation or mismeasurement?," Technical Report, National Bureau of Economic Research 2020.

Bloom, Nicholas, Charles I Jones, John Van Reenen, and Michael Webb, "Are ideas getting harder to find?," American Economic Review, 2020, 110 (4), 11041144.

Boskin, Michael, Ellen Dullberger, Robert J. Gordon, Zvi Grilliches, and Dale Jorgenson, "Toward a more accurate measure of the cost of living: Final report of the Senate Finance Committee from the Advisory Commission to Study the Consumer Price Index," Advisory Commission to Study the Consumer Price Index, 1996.

Brynjolfsson, Erik, Avinash Collis, W Erwin Diewert, Felix Eggers, and Kevin J Fox, "GDP-B: Accounting for the value of new and free goods in the digital economy," Technical Report, National Bureau of Economic Research 2019.

_ , Daniel Rock, and Chad Syverson, "The productivity J-curve: How intangibles complement general purpose technologies," American Economic Journal: Macroeconomics, 2021, 13 (1), 333-72. 
Byrne, David M., John G. Fernald, and Marshall B. Reinsdorf, "Does the United States Have a Productivity Slowdown or a Measurement Problem?," Brookings Papers on Economic Activity, 2016, 2016 (1), 109-182.

Chikis, Craig, Jonathan E Goldberg, and J David López-Salido, "Do Low Interest Rates Harm Innovation, Competition, and Productivity Growth?, Technical Report, CEPR Discussion Papers 2021.

Crouzet, Nicolas and Janice C Eberly, "Intangibles, Markups, and the Measurement of Productivity Growth," Working Paper 29109, National Bureau of Economic Research July 2021.

Edmond, Chris, Virgiliu Midrigan, and Daniel Yi Xu, "How costly are markups?," Technical Report, National Bureau of Economic Research 2018.

Farhi, Emmanuel and François Gourio, "Accounting for macro-finance trends: Market power, intangibles, and risk premia," Brookings Papers on Economic Activity, 2018, 2, 147-250.

Fernald, John and Brent Neiman, "Growth accounting with misallocation: Or, doing less with more in Singapore," American Economic Journal: Macroeconomics, 2011, 3 (2), 29-74.

Fernald, John G., "Productivity and Potential Output before, during, and after the Great Recession," NBER Macroeconomics Annual, 2015, 29 (1), 1-51.

Fernald, John, Huiyu Li, and Mitchell Ochse, "Labor productivity in a pandemic," FRBSF Economic Letter, 2021.

Gordon, Robert J, "Perspectives on the rise and fall of American growth," American Economic Review, 2016, 106 (5), 72-76.

Greenwood, Jeremy, Zvi Hercowitz, and Per Krusell, "Long-run implications of investment-specific technological change," The American economic review, 1997, pp. 342-362. 
Gutierrez, Germán and Thomas Philippon, "Declining Competition and Investment in the U.S.," Working Paper 23583, National Bureau of Economic Research July 2017.

Guvenen, Fatih, Raymond J Mataloni, Dylan G Rassier, and Kim J Ruhl, "Offshore profit shifting and domestic productivity measurement," Technical Report, National Bureau of Economic Research 2017.

Hall, Robert E and Charles I Jones, "Why do some countries produce so much more output per worker than others?," The Quarterly Journal of Economics, 1999, 114 (1), 83-116.

Hopenhayn, Hugo, Julian Neira, and Rish Singhania, "From population growth to firm demographics: Implications for concentration, entrepreneurship and the labor share," Technical Report 2020.

Hsieh, Chang-Tai and Peter J Klenow, "Relative prices and relative prosperity," American Economic Review, 2007, 97 (3), 562-585.

Hulten, Charles and Leonard I Nakamura, "Expanded GDP for Welfare Measurement in the 21st Century," in "Measuring and Accounting for Innovation in the 21st Century," University of Chicago Press, 2019.

Klenow, Peter J and Andres Rodriguez-Clare, "The neoclassical revival in growth economics: Has it gone too far?," NBER macroeconomics annual, 1997, 12, 73-103.

Koh, Dongya, Raül Santaeulàlia-Llopis, and Yu Zheng, "Labor share decline and intellectual property products capital," Econometrica, 2020, 88 (6), 26092628.

Kremer, Michael, Jack Willis, and Yang You, "Converging to Convergence," NBER Macroeconomic Annual, 2021, 36. 
Liu, Ernest, Atif Mian, and Amir Sufi, "Low interest rates, market power, and productivity growth," Econometrica, Forthcoming.

Loecker, Jan De, Jan Eeckhout, and Gabriel Unger, "The rise of market power and the macroeconomic implications," Quarterly Journal of Economics, 2020, 135 (2), 561-644.

Lucas, Robert E Jr., "On the mechanics of economic development," Journal of monetary economics, 1988, 22 (1), 3-42.

Moulton, Brent, “The Measurement of Output, Prices, and Productivity: What's Changed Since the Boskin Commission?," Technical Report, The Hutchins Center on Fiscal and Monetary Policy at the Brookings Institution 2018.

Peters, Michael and Conor Walsh, "Population growth and firm dynamics," working paper, 2020.

Prescott, Edward C, "Lawrence R. Klein lecture 1997: Needed: A theory of total factor productivity," International economic review, 1998, pp. 525-551.

Rodrik, Dani, “Unconditional convergence in manufacturing," The Quarterly Journal of Economics, 2013, 128 (1), 165-204.

Syverson, Chad, "Challenges to Mismeasurement Explanations for the U.S. Productivity Slowdown," Journal of Economic Perspectives, 2017, 31 (2), 165-186. 


\section{Appendix: additional figures and tables}

Figure A1: Growth rate of GDP, labor productivity and TFP in non-OECD countries

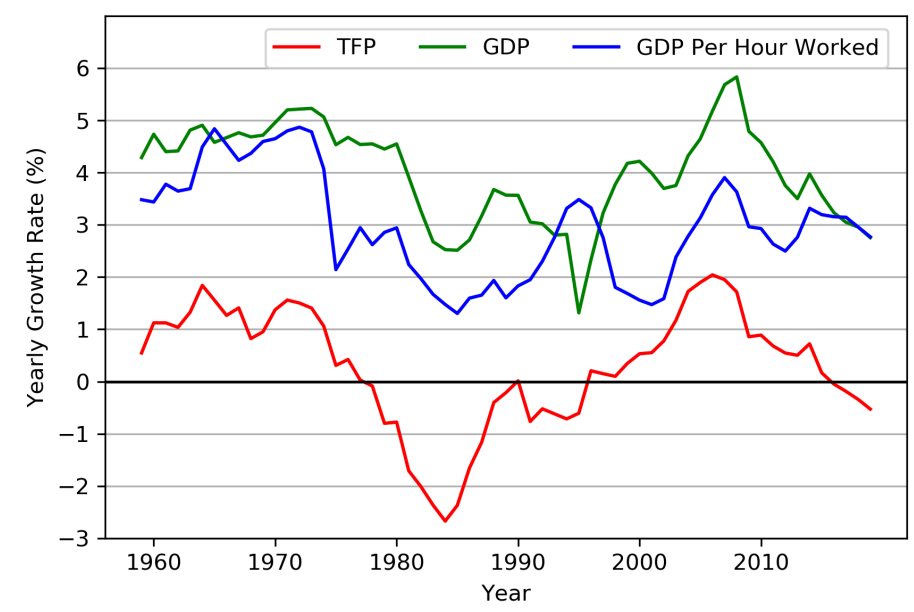

Source: Penn World Tables 10.0. 1960-2019. GDP = "rgdpna", TFP = "rtfpna", hours = "avh" times "emp", GDP per hours = "rgdpna" divided by hours. 5 year trailing moving averages. Average across countries is weighted by real GDP.

Figure A2: Convergence for 2000-2019

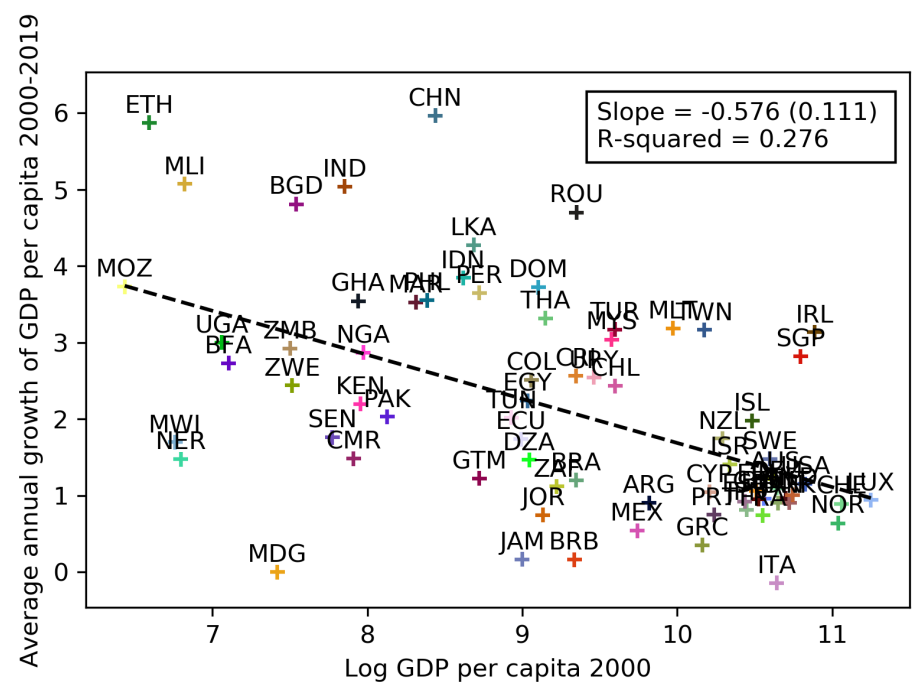

Source: Penn World Tables 10.0. Real GDP per capita = "rgdpna" divided by "pop". The x-axis plots the natural log of real GDP per capita in 2000. The y-axis plots the average annual growth rate of real GDP per capita over 2000-2019. 
Table A1: Development accounting with investment specific technology

\begin{tabular}{lcccc} 
Country & $Y / L$ & $\left(\Theta^{-1} K / Y\right)^{\frac{\alpha}{1-\alpha}}$ & $h$ & $A$ \\
\hline United States & 1.000 & 1.000 & 1.000 & 1.000 \\
Switzerland & 0.849 & 1.182 & 0.987 & 0.728 \\
France & 0.793 & 1.522 & 0.857 & 0.608 \\
Germany & 0.741 & 1.320 & 0.981 & 0.572 \\
Sweden & 0.831 & 1.250 & 0.915 & 0.726 \\
Japan & 0.561 & 1.290 & 0.957 & 0.454 \\
Republic of Korea & 0.589 & 1.626 & 0.996 & 0.364 \\
Russian Federation & 0.425 & 2.331 & 0.913 & 0.200 \\
Mexico & 0.364 & 1.972 & 0.736 & 0.251 \\
Argentina & 0.409 & 1.858 & 0.819 & 0.269 \\
Brazil & 0.243 & 1.906 & 0.806 & 0.158 \\
China & 0.184 & 1.806 & 0.714 & 0.142 \\
India & 0.141 & 2.606 & 0.574 & 0.094 \\
Nigeria & 0.112 & 2.018 & 0.521 & 0.106 \\
Kenya & 0.068 & 1.802 & 0.621 & 0.061 \\
Zimbabwe & 0.049 & 1.230 & 0.716 & 0.056
\end{tabular}

Source: Penn World Tables 10.0. $\tilde{Y}=$ "rgdpo", s = natural resource shares from World Development Index, $\mathrm{Y}=\tilde{Y}(1-s)$ times "pl_gdpo" divided by "pl_con", L = "emp", $\mathrm{K}=$ "rnna" /"pl_n", $\mathrm{h}=$ "hc", $\Theta^{-1}=$ "pl_i" divided by "pl_con". $A=\frac{Y}{\left(\Theta^{-1} K / Y\right)^{\frac{\alpha}{1-\alpha}} h L}$ with $\alpha=1 / 3$. 


\begin{tabular}{|c|c|c|c|c|}
\hline Country & $Y / L$ & $(K / Y)^{\frac{\alpha}{1-\alpha}}$ & $h$ & A \\
\hline Ireland & 1.574 & 1.050 & 0.846 & 1.772 \\
\hline China, Macao SAR & 1.276 & 0.996 & 0.778 & 1.648 \\
\hline Norway & 1.032 & 1.156 & 0.976 & 0.914 \\
\hline Singapore & 1.004 & 1.136 & 1.110 & 0.797 \\
\hline Switzerland & 1.002 & 1.214 & 0.987 & 0.836 \\
\hline United States & 1.000 & 1.000 & 1.000 & 1.000 \\
\hline Qatar & 0.979 & 1.313 & 0.848 & 0.880 \\
\hline Luxembourg & 0.942 & 1.220 & 0.952 & 0.811 \\
\hline Brunei Darussalam & 0.867 & 1.593 & 0.744 & 0.731 \\
\hline China, Hong Kong SAR & 0.828 & 1.356 & 0.869 & 0.703 \\
\hline Belgium & 0.821 & 1.412 & 0.839 & 0.693 \\
\hline Austria & 0.820 & 1.332 & 0.900 & 0.684 \\
\hline France & 0.806 & 1.342 & 0.857 & 0.701 \\
\hline Sweden & 0.805 & 1.248 & 0.915 & 0.705 \\
\hline Denmark & 0.790 & 1.247 & 0.956 & 0.662 \\
\hline Netherlands & 0.785 & 1.214 & 0.903 & 0.716 \\
\hline Australia & 0.775 & 1.168 & 0.944 & 0.702 \\
\hline Bahrain & 0.767 & 1.272 & 0.597 & 1.011 \\
\hline
\end{tabular}




\begin{tabular}{|c|c|c|c|c|}
\hline Country & $Y / L$ & $(K / Y)^{\frac{\alpha}{1-\alpha}}$ & $h$ & $A$ \\
\hline Italy & 0.756 & 1.501 & 0.839 & 0.601 \\
\hline Germany & 0.753 & 1.194 & 0.981 & 0.642 \\
\hline Spain & 0.741 & 1.360 & 0.792 & 0.688 \\
\hline Canada & 0.738 & 1.186 & 0.992 & 0.627 \\
\hline Finland & 0.722 & 1.236 & 0.931 & 0.627 \\
\hline Saudi Arabia & 0.715 & 1.287 & 0.719 & 0.773 \\
\hline United Arab Emirates & 0.714 & 1.572 & 0.733 & 0.620 \\
\hline United Kingdom & 0.709 & 1.226 & 1.006 & 0.575 \\
\hline Iceland & 0.683 & 1.270 & 0.869 & 0.619 \\
\hline Malta & 0.626 & 1.020 & 0.840 & 0.731 \\
\hline Republic of Korea & 0.624 & 1.229 & 0.996 & 0.510 \\
\hline Turkey & 0.614 & 1.132 & 0.662 & 0.819 \\
\hline Israel & 0.603 & 1.044 & 1.028 & 0.561 \\
\hline Cyprus & 0.590 & 1.522 & 0.770 & 0.503 \\
\hline New Zealand & 0.584 & 1.001 & 0.904 & 0.645 \\
\hline Japan & 0.565 & 1.236 & 0.957 & 0.477 \\
\hline Czech Republic & 0.562 & 1.331 & 0.980 & 0.431 \\
\hline Poland & 0.554 & 0.884 & 0.916 & 0.683 \\
\hline
\end{tabular}




\begin{tabular}{|c|c|c|c|c|}
\hline Country & $Y / L$ & $(K / Y)^{\frac{\alpha}{1-\alpha}}$ & $h$ & $A$ \\
\hline Slovenia & 0.531 & 1.439 & 0.949 & 0.389 \\
\hline Greece & 0.526 & 1.651 & 0.832 & 0.383 \\
\hline Panama & 0.523 & 1.070 & 0.767 & 0.637 \\
\hline Kuwait & 0.508 & 1.342 & 0.603 & 0.628 \\
\hline Portugal & 0.503 & 1.638 & 0.667 & 0.460 \\
\hline Estonia & 0.497 & 1.219 & 0.972 & 0.419 \\
\hline Lithuania & 0.489 & 1.123 & 0.876 & 0.497 \\
\hline Latvia & 0.474 & 1.567 & 0.839 & 0.360 \\
\hline Slovakia & 0.468 & 1.241 & 1.021 & 0.369 \\
\hline Romania & 0.461 & 0.999 & 0.869 & 0.531 \\
\hline Hungary & 0.456 & 1.230 & 0.908 & 0.408 \\
\hline Croatia & 0.452 & 1.301 & 0.954 & 0.364 \\
\hline Trinidad and Tobago & 0.435 & 0.813 & 0.822 & 0.651 \\
\hline Maldives & 0.408 & 1.301 & 0.665 & 0.471 \\
\hline Mauritius & 0.391 & 0.981 & 0.699 & 0.570 \\
\hline Argentina & 0.388 & 0.995 & 0.819 & 0.476 \\
\hline Malaysia & 0.384 & 1.183 & 0.816 & 0.398 \\
\hline Russian Federation & 0.379 & 1.277 & 0.913 & 0.325 \\
\hline
\end{tabular}




\begin{tabular}{|c|c|c|c|c|}
\hline Country & $Y / L$ & $(K / Y)^{\frac{\alpha}{1-\alpha}}$ & $h$ & $A$ \\
\hline Chile & 0.376 & 1.241 & 0.835 & 0.363 \\
\hline Jordan & 0.350 & 0.972 & 0.771 & 0.467 \\
\hline Mexico & 0.341 & 1.165 & 0.736 & 0.397 \\
\hline Kazakhstan & 0.340 & 0.931 & 0.834 & 0.437 \\
\hline Egypt & 0.339 & 0.674 & 0.707 & 0.711 \\
\hline Bulgaria & 0.334 & 0.959 & 0.848 & 0.411 \\
\hline Uruguay & 0.334 & 1.156 & 0.736 & 0.392 \\
\hline Costa Rica & 0.322 & 0.866 & 0.715 & 0.520 \\
\hline Armenia & 0.317 & 0.873 & 0.837 & 0.433 \\
\hline Serbia & 0.316 & 1.255 & 0.917 & 0.275 \\
\hline Fiji & 0.314 & 0.815 & 0.719 & 0.536 \\
\hline Botswana & 0.308 & 1.202 & 0.778 & 0.329 \\
\hline Gabon & 0.303 & 1.222 & 0.756 & 0.328 \\
\hline South Africa & 0.291 & 1.098 & 0.763 & 0.347 \\
\hline Algeria & 0.284 & 1.323 & 0.626 & 0.343 \\
\hline Dominican Republic & 0.282 & 1.092 & 0.730 & 0.354 \\
\hline Sri Lanka & 0.269 & 0.916 & 0.764 & 0.385 \\
\hline Tunisia & 0.265 & 0.908 & 0.709 & 0.412 \\
\hline
\end{tabular}




\begin{tabular}{|c|c|c|c|c|}
\hline Country & $Y / L$ & $(K / Y)^{\frac{\alpha}{1-\alpha}}$ & $h$ & $A$ \\
\hline Ukraine & 0.258 & 1.965 & 0.876 & 0.150 \\
\hline Albania & 0.252 & 1.382 & 0.790 & 0.231 \\
\hline Brazil & 0.247 & 1.173 & 0.806 & 0.261 \\
\hline Eswatini & 0.245 & 0.989 & 0.558 & 0.444 \\
\hline Thailand & 0.239 & 1.191 & 0.741 & 0.270 \\
\hline Namibia & 0.239 & 1.022 & 0.598 & 0.391 \\
\hline Colombia & 0.237 & 0.983 & 0.689 & 0.349 \\
\hline Iraq & 0.224 & 1.148 & 0.608 & 0.320 \\
\hline Barbados & 0.201 & 1.706 & 0.759 & 0.156 \\
\hline Paraguay & 0.201 & 0.982 & 0.703 & 0.292 \\
\hline Republic of Moldova & 0.199 & 0.950 & 0.939 & 0.223 \\
\hline China & 0.190 & 1.189 & 0.714 & 0.224 \\
\hline Morocco & 0.189 & 1.259 & 0.511 & 0.294 \\
\hline Indonesia & 0.177 & 1.311 & 0.615 & 0.219 \\
\hline Ecuador & 0.173 & 1.358 & 0.736 & 0.173 \\
\hline Peru & 0.167 & 1.081 & 0.753 & 0.205 \\
\hline Philippines & 0.165 & 0.934 & 0.721 & 0.244 \\
\hline Jamaica & 0.157 & 1.349 & 0.693 & 0.168 \\
\hline
\end{tabular}




\begin{tabular}{|c|c|c|c|c|}
\hline Country & $Y / L$ & $(K / Y)^{\frac{\alpha}{1-\alpha}}$ & $h$ & A \\
\hline Guatemala & 0.147 & 1.002 & 0.516 & 0.284 \\
\hline India & 0.139 & 1.065 & 0.574 & 0.227 \\
\hline El Salvador & 0.137 & 1.043 & 0.607 & 0.217 \\
\hline Pakistan & 0.132 & 0.689 & 0.473 & 0.404 \\
\hline Bolivia (Plurinational State of) & 0.129 & 0.829 & 0.785 & 0.198 \\
\hline Côte d'Ivoire & 0.126 & 0.763 & 0.448 & 0.370 \\
\hline Mauritania & 0.125 & 1.269 & 0.482 & 0.204 \\
\hline Mongolia & 0.118 & 1.543 & 0.808 & 0.095 \\
\hline Belize & 0.112 & 1.139 & 0.954 & 0.103 \\
\hline Sudan & 0.109 & 0.813 & 0.428 & 0.313 \\
\hline Lao People's DR & 0.106 & 1.037 & 0.515 & 0.199 \\
\hline Kyrgyzstan & 0.105 & 0.835 & 0.935 & 0.134 \\
\hline Honduras & 0.101 & 1.155 & 0.639 & 0.137 \\
\hline Nigeria & 0.099 & 1.007 & 0.521 & 0.188 \\
\hline Nicaragua & 0.097 & 1.096 & 0.605 & 0.146 \\
\hline Viet Nam & 0.096 & 0.904 & 0.752 & 0.140 \\
\hline Tajikistan & 0.095 & 1.821 & 0.812 & 0.065 \\
\hline Bangladesh & 0.086 & 1.040 & 0.554 & 0.150 \\
\hline
\end{tabular}




\begin{tabular}{|c|c|c|c|c|}
\hline Country & $Y / L$ & $(K / Y)^{\frac{\alpha}{1-\alpha}}$ & $h$ & $A$ \\
\hline Myanmar & 0.085 & 0.946 & 0.489 & 0.185 \\
\hline Angola & 0.083 & 1.529 & 0.394 & 0.138 \\
\hline Ghana & 0.079 & 0.961 & 0.667 & 0.124 \\
\hline Yemen & 0.071 & 1.809 & 0.477 & 0.082 \\
\hline Zambia & 0.070 & 1.377 & 0.706 & 0.072 \\
\hline Kenya & 0.068 & 0.852 & 0.621 & 0.128 \\
\hline Cameroon & 0.066 & 0.905 & 0.506 & 0.145 \\
\hline Benin & 0.066 & 0.826 & 0.502 & 0.159 \\
\hline Lesotho & 0.065 & 1.198 & 0.462 & 0.118 \\
\hline Senegal & 0.065 & 0.952 & 0.427 & 0.159 \\
\hline Cambodia & 0.063 & 0.912 & 0.516 & 0.133 \\
\hline Gambia & 0.062 & 0.801 & 0.440 & 0.177 \\
\hline Mali & 0.054 & 0.692 & 0.364 & 0.213 \\
\hline Nepal & 0.050 & 0.986 & 0.480 & 0.106 \\
\hline Zimbabwe & 0.048 & 0.703 & 0.716 & 0.095 \\
\hline Congo & 0.047 & 1.885 & 0.546 & 0.045 \\
\hline Sierra Leone & 0.044 & 0.598 & 0.435 & 0.170 \\
\hline Uganda & 0.042 & 0.797 & 0.636 & 0.082 \\
\hline
\end{tabular}

Continued on next page 


\begin{tabular}{|c|c|c|c|c|}
\hline Country & $Y / L$ & $(K / Y)^{\frac{\alpha}{1-\alpha}}$ & $h$ & $A$ \\
\hline U.R. of Tanzania: Mainland & 0.041 & 0.929 & 0.455 & 0.098 \\
\hline Burkina Faso & 0.040 & 0.816 & 0.340 & 0.146 \\
\hline Rwanda & 0.039 & 0.724 & 0.501 & 0.108 \\
\hline Togo & 0.038 & 0.950 & 0.479 & 0.084 \\
\hline Ethiopia & 0.032 & 0.840 & 0.383 & 0.101 \\
\hline Haiti & 0.031 & 1.592 & 0.458 & 0.042 \\
\hline Liberia & 0.025 & 1.089 & 0.487 & 0.048 \\
\hline Niger & 0.023 & 1.211 & 0.325 & 0.058 \\
\hline Mozambique & 0.023 & 1.000 & 0.327 & 0.069 \\
\hline Madagascar & 0.022 & 0.868 & 0.458 & 0.056 \\
\hline D.R. of the Congo & 0.020 & 1.098 & 0.447 & 0.041 \\
\hline Malawi & 0.020 & 0.602 & 0.534 & 0.061 \\
\hline Central African Republic & 0.018 & 1.515 & 0.414 & 0.028 \\
\hline Burundi & 0.013 & 0.815 & 0.375 & 0.042 \\
\hline
\end{tabular}

Source: Penn World Tables 10.0. $\tilde{Y}=$ "rgdpo", s = natural resource shares from World Development Index, $Y=\tilde{Y}(1-s), \mathrm{L}=$ "emp", $\mathrm{K}=$ "cn", $\mathrm{h}=$ "hc". $A=\frac{Y}{(K / Y)^{\frac{\alpha}{1-\alpha}} h L}$ with $\alpha=1 / 3$. 


\begin{tabular}{|c|c|c|c|c|}
\hline Country & $Y / L$ & $\left(\Theta^{-1} K / Y\right)^{\frac{\alpha}{1-\alpha}}$ & $h$ & $A$ \\
\hline China, Macao SAR & 1.422 & 1.307 & 0.778 & 1.399 \\
\hline Ireland & 1.227 & 1.270 & 0.846 & 1.142 \\
\hline Singapore & 1.052 & 1.623 & 1.110 & 0.584 \\
\hline Luxembourg & 1.018 & 1.165 & 0.952 & 0.917 \\
\hline United States & 1.000 & 1.000 & 1.000 & 1.000 \\
\hline Brunei Darussalam & 0.935 & 3.154 & 0.744 & 0.398 \\
\hline China, Hong Kong SAR & 0.917 & 1.649 & 0.869 & 0.640 \\
\hline Switzerland & 0.849 & 1.182 & 0.987 & 0.728 \\
\hline Belgium & 0.839 & 1.538 & 0.839 & 0.649 \\
\hline Sweden & 0.831 & 1.250 & 0.915 & 0.726 \\
\hline Norway & 0.823 & 1.203 & 0.976 & 0.701 \\
\hline Austria & 0.801 & 1.490 & 0.900 & 0.597 \\
\hline France & 0.793 & 1.522 & 0.857 & 0.608 \\
\hline Malta & 0.773 & 1.316 & 0.840 & 0.699 \\
\hline Denmark & 0.759 & 1.218 & 0.956 & 0.652 \\
\hline Finland & 0.747 & 1.267 & 0.931 & 0.634 \\
\hline Iceland & 0.746 & 1.060 & 0.869 & 0.810 \\
\hline Germany & 0.741 & 1.320 & 0.981 & 0.572 \\
\hline
\end{tabular}




\begin{tabular}{|c|c|c|c|c|}
\hline Country & $Y / L$ & $\left(\Theta^{-1} K / Y\right)^{\frac{\alpha}{1-\alpha}}$ & $h$ & A \\
\hline Australia & 0.741 & 1.207 & 0.944 & 0.650 \\
\hline Netherlands & 0.732 & 1.349 & 0.903 & 0.601 \\
\hline Canada & 0.723 & 1.364 & 0.992 & 0.535 \\
\hline Saudi Arabia & 0.707 & 2.530 & 0.719 & 0.389 \\
\hline Italy & 0.705 & 1.899 & 0.839 & 0.443 \\
\hline Bahrain & 0.705 & 2.403 & 0.597 & 0.492 \\
\hline Spain & 0.704 & 1.781 & 0.792 & 0.499 \\
\hline Qatar & 0.682 & 2.179 & 0.848 & 0.369 \\
\hline United Kingdom & 0.681 & 1.371 & 1.006 & 0.494 \\
\hline Cyprus & 0.677 & 1.865 & 0.770 & 0.472 \\
\hline Israel & 0.631 & 1.078 & 1.028 & 0.569 \\
\hline New Zealand & 0.613 & 0.975 & 0.904 & 0.696 \\
\hline United Arab Emirates & 0.612 & 2.756 & 0.733 & 0.303 \\
\hline Czech Republic & 0.610 & 1.897 & 0.980 & 0.328 \\
\hline Republic of Korea & 0.589 & 1.626 & 0.996 & 0.364 \\
\hline Poland & 0.586 & 1.459 & 0.916 & 0.438 \\
\hline Turkey & 0.583 & 2.492 & 0.662 & 0.353 \\
\hline Slovenia & 0.577 & 1.955 & 0.949 & 0.311 \\
\hline
\end{tabular}




\begin{tabular}{|c|c|c|c|c|}
\hline Country & $Y / L$ & $\left(\Theta^{-1} K / Y\right)^{\frac{\alpha}{1-\alpha}}$ & $h$ & $A$ \\
\hline Lithuania & 0.570 & 1.719 & 0.876 & 0.378 \\
\hline Japan & 0.561 & 1.290 & 0.957 & 0.454 \\
\hline Panama & 0.558 & 1.865 & 0.767 & 0.390 \\
\hline Slovakia & 0.545 & 1.723 & 1.021 & 0.310 \\
\hline Estonia & 0.543 & 1.662 & 0.972 & 0.336 \\
\hline Greece & 0.541 & 2.402 & 0.832 & 0.271 \\
\hline Hungary & 0.530 & 1.955 & 0.908 & 0.298 \\
\hline Portugal & 0.509 & 2.341 & 0.667 & 0.326 \\
\hline Latvia & 0.497 & 2.301 & 0.839 & 0.257 \\
\hline Romania & 0.476 & 1.802 & 0.869 & 0.304 \\
\hline Croatia & 0.461 & 2.079 & 0.954 & 0.232 \\
\hline Kuwait & 0.445 & 2.396 & 0.603 & 0.308 \\
\hline Russian Federation & 0.425 & 2.331 & 0.913 & 0.200 \\
\hline Trinidad and Tobago & 0.421 & 1.294 & 0.822 & 0.396 \\
\hline Malaysia & 0.419 & 2.343 & 0.816 & 0.219 \\
\hline Kazakhstan & 0.410 & 1.874 & 0.834 & 0.262 \\
\hline Argentina & 0.409 & 1.858 & 0.819 & 0.269 \\
\hline Mauritius & 0.404 & 1.839 & 0.699 & 0.314 \\
\hline
\end{tabular}




\begin{tabular}{|c|c|c|c|c|}
\hline Country & $Y / L$ & $\left(\Theta^{-1} K / Y\right)^{\frac{\alpha}{1-\alpha}}$ & $h$ & A \\
\hline Maldives & 0.398 & 2.533 & 0.665 & 0.236 \\
\hline Chile & 0.369 & 1.879 & 0.835 & 0.235 \\
\hline Mexico & 0.364 & 1.972 & 0.736 & 0.251 \\
\hline Bulgaria & 0.364 & 1.739 & 0.848 & 0.247 \\
\hline Uruguay & 0.350 & 1.549 & 0.736 & 0.307 \\
\hline Costa Rica & 0.350 & 1.327 & 0.715 & 0.369 \\
\hline Algeria & 0.347 & 2.908 & 0.626 & 0.191 \\
\hline Botswana & 0.338 & 2.253 & 0.778 & 0.193 \\
\hline Jordan & 0.333 & 1.977 & 0.771 & 0.218 \\
\hline Serbia & 0.333 & 2.458 & 0.917 & 0.148 \\
\hline Armenia & 0.327 & 1.899 & 0.837 & 0.206 \\
\hline Gabon & 0.326 & 2.158 & 0.756 & 0.200 \\
\hline Egypt & 0.319 & 1.995 & 0.707 & 0.226 \\
\hline South Africa & 0.302 & 2.095 & 0.763 & 0.189 \\
\hline Fiji & 0.292 & 1.511 & 0.719 & 0.269 \\
\hline Dominican Republic & 0.286 & 2.115 & 0.730 & 0.185 \\
\hline Tunisia & 0.280 & 2.247 & 0.709 & 0.176 \\
\hline Barbados & 0.278 & 1.785 & 0.759 & 0.205 \\
\hline
\end{tabular}




\begin{tabular}{|c|c|c|c|c|}
\hline Country & $Y / L$ & $\left(\Theta^{-1} K / Y\right)^{\frac{\alpha}{1-\alpha}}$ & $h$ & $A$ \\
\hline Sri Lanka & 0.278 & 2.167 & 0.764 & 0.168 \\
\hline Ukraine & 0.267 & 5.628 & 0.876 & 0.054 \\
\hline Namibia & 0.261 & 1.784 & 0.598 & 0.245 \\
\hline Eswatini & 0.258 & 1.976 & 0.558 & 0.234 \\
\hline Thailand & 0.258 & 2.640 & 0.741 & 0.132 \\
\hline Albania & 0.256 & 2.719 & 0.790 & 0.119 \\
\hline Colombia & 0.249 & 1.733 & 0.689 & 0.209 \\
\hline Brazil & 0.243 & 1.906 & 0.806 & 0.158 \\
\hline Iraq & 0.219 & 2.124 & 0.608 & 0.170 \\
\hline Paraguay & 0.214 & 1.806 & 0.703 & 0.168 \\
\hline Republic of Moldova & 0.204 & 2.115 & 0.939 & 0.103 \\
\hline China & 0.184 & 1.806 & 0.714 & 0.142 \\
\hline Morocco & 0.177 & 2.545 & 0.511 & 0.136 \\
\hline Jamaica & 0.177 & 2.091 & 0.693 & 0.122 \\
\hline Indonesia & 0.175 & 3.064 & 0.615 & 0.093 \\
\hline Ecuador & 0.172 & 2.401 & 0.736 & 0.097 \\
\hline Peru & 0.171 & 1.804 & 0.753 & 0.126 \\
\hline Philippines & 0.167 & 2.043 & 0.721 & 0.113 \\
\hline
\end{tabular}




\begin{tabular}{|c|c|c|c|c|}
\hline Country & $Y / L$ & $\left(\Theta^{-1} K / Y\right)^{\frac{\alpha}{1-\alpha}}$ & $h$ & $A$ \\
\hline Guatemala & 0.147 & 1.643 & 0.516 & 0.173 \\
\hline Mongolia & 0.142 & 3.581 & 0.808 & 0.049 \\
\hline India & 0.141 & 2.606 & 0.574 & 0.094 \\
\hline El Salvador & 0.141 & 2.026 & 0.607 & 0.114 \\
\hline Bolivia (Plurinational State of) & 0.135 & 1.639 & 0.785 & 0.105 \\
\hline Belize & 0.135 & 1.662 & 0.954 & 0.085 \\
\hline Côte d'Ivoire & 0.134 & 1.492 & 0.448 & 0.201 \\
\hline Pakistan & 0.130 & 1.798 & 0.473 & 0.153 \\
\hline Mauritania & 0.129 & 2.700 & 0.482 & 0.099 \\
\hline Nigeria & 0.112 & 2.018 & 0.521 & 0.106 \\
\hline Sudan & 0.111 & 2.393 & 0.428 & 0.108 \\
\hline Lao People's DR & 0.108 & 2.491 & 0.515 & 0.084 \\
\hline Nicaragua & 0.105 & 2.229 & 0.605 & 0.078 \\
\hline Viet Nam & 0.102 & 2.024 & 0.752 & 0.067 \\
\hline Honduras & 0.099 & 2.211 & 0.639 & 0.070 \\
\hline Kyrgyzstan & 0.097 & 2.308 & 0.935 & 0.045 \\
\hline Ghana & 0.092 & 1.934 & 0.667 & 0.071 \\
\hline Bangladesh & 0.091 & 2.318 & 0.554 & 0.071 \\
\hline
\end{tabular}




\begin{tabular}{|c|c|c|c|c|}
\hline Country & $Y / L$ & $\left(\Theta^{-1} K / Y\right)^{\frac{\alpha}{1-\alpha}}$ & $h$ & $A$ \\
\hline Myanmar & 0.090 & 2.502 & 0.489 & 0.074 \\
\hline Angola & 0.085 & 3.107 & 0.394 & 0.069 \\
\hline Tajikistan & 0.084 & 4.669 & 0.812 & 0.022 \\
\hline Zambia & 0.079 & 2.642 & 0.706 & 0.042 \\
\hline Cameroon & 0.070 & 1.797 & 0.506 & 0.077 \\
\hline Senegal & 0.069 & 1.898 & 0.427 & 0.085 \\
\hline Benin & 0.069 & 1.733 & 0.502 & 0.079 \\
\hline Kenya & 0.068 & 1.802 & 0.621 & 0.061 \\
\hline Lesotho & 0.067 & 2.500 & 0.462 & 0.058 \\
\hline Cambodia & 0.062 & 2.132 & 0.516 & 0.056 \\
\hline Gambia & 0.060 & 1.965 & 0.440 & 0.069 \\
\hline Yemen & 0.058 & 3.305 & 0.477 & 0.037 \\
\hline Congo & 0.054 & 3.417 & 0.546 & 0.029 \\
\hline Mali & 0.054 & 1.402 & 0.364 & 0.107 \\
\hline U.R. of Tanzania: Mainland & 0.050 & 1.892 & 0.455 & 0.059 \\
\hline Zimbabwe & 0.049 & 1.230 & 0.716 & 0.056 \\
\hline Nepal & 0.048 & 2.489 & 0.480 & 0.040 \\
\hline Uganda & 0.046 & 1.789 & 0.636 & 0.040 \\
\hline
\end{tabular}




\begin{tabular}{|c|c|c|c|c|}
\hline Country & $Y / L$ & $\left(\Theta^{-1} K / Y\right)^{\frac{\alpha}{1-\alpha}}$ & $h$ & $A$ \\
\hline Sierra Leone & 0.044 & 1.598 & 0.435 & 0.064 \\
\hline Burkina Faso & 0.042 & 1.733 & 0.340 & 0.072 \\
\hline Rwanda & 0.040 & 1.519 & 0.501 & 0.052 \\
\hline Togo & 0.039 & 1.938 & 0.479 & 0.042 \\
\hline Ethiopia & 0.034 & 1.964 & 0.383 & 0.045 \\
\hline Haiti & 0.030 & 2.791 & 0.458 & 0.024 \\
\hline Liberia & 0.025 & 2.126 & 0.487 & 0.024 \\
\hline Niger & 0.024 & 2.378 & 0.325 & 0.031 \\
\hline Madagascar & 0.024 & 1.870 & 0.458 & 0.028 \\
\hline Mozambique & 0.023 & 1.952 & 0.327 & 0.036 \\
\hline D.R. of the Congo & 0.022 & 1.903 & 0.447 & 0.025 \\
\hline Malawi & 0.020 & 1.257 & 0.534 & 0.030 \\
\hline Central African Republic & 0.018 & 2.991 & 0.414 & 0.015 \\
\hline Burundi & 0.013 & 1.821 & 0.375 & 0.019 \\
\hline
\end{tabular}

Source: Penn World Tables 10.0. $\tilde{Y}=$ "rgdpo", s = natural resource shares from World Development Index, $\mathrm{Y}=\tilde{Y}(1-s)$ times "pl_gdpo" divided by “pl_con”, L = "emp", K = "rnna”/"pl_n”, h = "hc", $\Theta^{-1}=$ "pl_i" divided by "pl_con". $A=\frac{Y}{\left(\Theta^{-1} K / Y\right)^{\frac{\alpha}{1-\alpha}} h L}$ with $\alpha=1 / 3$. 